\title{
Interaction of oceanography patterns towards the abundance of phytoplankton, zooplankton and ichthyoplankton in teluk penyu waters of Cilacap
}

\author{
Florencius Eko Dwi Haryono ${ }^{1 *}$, Rose Dewi ${ }^{1}$, Taufik Budhi Pramono ${ }^{2}$, Rifki Ahda Sumantri ${ }^{1}$, Tri Nur Cahyo ${ }^{1}$, \\ Dewi Wisudyanti ${ }^{1}$ \\ ${ }^{1}$ Marine Science Department. Faculty of Fisheries and Marine Science. Jenderal Soedirman University, Purwokerto-
Banyumas
${ }^{2}$ Aquaculture Study Programe of Jenderal Soedirman University. Purwokerto, Banyumas
}

\begin{abstract}
Coastal waters of Teluk Penyu-Cilacap district is an enlarging area for many species of fish larvae. The waters is directly influenced by the physical, chemical and biological of Indian Ocean patterns. Fish communities inhabit in gulf waters to take advantage of the high productivity in the coastal waters to support their livelihoods. The gulf area is usually associate with other productive ecosystems i.e. rivers that empties into it and mangrove forests. The study aim is to analyze the influence of oceanography pattern to the existence of ichthyoplankton [fish larvae] inhabit at Teluk Penyu waters of Cilacap district. Sampling is conducted monthly from April - June 2009 at 3 sites. The sites were set 1 mile of distance from coastline at Teluk Penyu Cilacap, PPSC and RSPC waters. Fish larvae were collected using larvae net mesh size $0.5 \mathrm{~mm}$ and $75 \mathrm{~cm}$ mouth diameter and phytoplankton and zooplankton are collected using plankton net. Larvae net was towed on the surface of the waters using a motorized boat with a speed 1 knot. Data were analyzed statistically based on Principal Components Analysis/PCA. 30 species of phytoplankton and 25 species of zooplankton species were identified from the waters. The species of phytoplankton and zooplankton were obtained difference species at each site. The highest abundance of phytoplankton were species of Chaetoceros and the abundance of zooplankton from the highest subsequence are species of Coelosphaerium dubium and Platydorina. The highest of relative abundance of ichthyoplankton in Teluk Penyu tourism waters was obtained $41,463 \%$ of the crawfish [Crumrnophthalmus spp.], followed by pheasant fish [Auriglobus nefastus] $8.53667 \%$, and swordfish (Chirocentrus dorab spp.) 2.439\%, and fish beloso [Tumbilic saurida] and gulamah fish (Johnius dussumieri) which are $1.2195 \%$. The abundance of phytoplankton and zooplankton associated to ichthyoplankton abundance. The Southern of Teluk Penyu gulf waters was highest abundance area of ichthyoplankton.
\end{abstract}

\section{Introduction}

Bay, lagoon, and mangrove forests are part of coastal ecosystems that have a very important role to fish survival. Those areas are care for several important species such as fish and shrimp [23]. The fish community utilizes the high productivity in the coastal areas to support their lives. This area usually associated with other productive ecosystems such as rivers that lead to it and mangrove forests [7]. The estuary adjacent coastal waters is also an important support for fisheries activities [2].

Ecosystem of Teluk Penyu waters at Cilacap district is a very dynamic area. These waters are heavily influenced by the physical, chemical, and biological conditions of the Indian Ocean i.e. the current, wind, tidal, wave, and salinity and $\mathrm{DO}, \mathrm{pH}$, nitrate, nitrite and biological conditions. These ecosystem also inseparable influence of Segara Anakan mangrove ecosystem which gives a lot of nutrient inputs that affect to the fertility of the waters, and support the life of various species of fish and shrimp. The ecological function of Teluk Penyu coastal waters is enlarging area for many species of fish larvae that supported of the enrichment of nutrients. The high diversity of fish larvae in the waters illustrates the high support of the ecosystem towards the continuity of fishery activities. The main objective of fisheries management utilize the existing of fishery resources maximally while maintaining the sustainability of the resource that is being exploited. In order to preserve fishery resources, information on biological and ecological aspects of fishery resources is needed, especially in the case of the species, abundance and distribution of fish larvae in Teluk Penyu.

The larvae are the stage or level of fish after the eggs hatch until the egg yolk is absorbed [6]. The uses term of larvae which refer to the egg yolk larvae and post larvae for young fish between larvae and juvenile stadia. Stadia larvae is terminated when the egg yolks have been absorbed [21]. Divide the phases of fish life into egg phase, larval pre flexion, larval flexion, larval post flexion, larval transition, juvenile and adult [13]. The newly, 
hatched larvae are marked by (a) the presence of an egg yolk sac located at the bottom of the front and (b) a fingerless fin that surrounds the body of the larvae, from the back, tail, to the bottom just behind the anus. In some types of fish the boundary of the circumference fins are located just behind the yolk sac [20]. The development of larvae in the outline is divided into 2 stages namely pro larvae and post larvae. Distinguish the pro larvae has an egg yolk sac, transparent body with several pigment tails whose function is unknown. The pectoral and tail fins are present but are not yet perfectly shaped and most of the newly released pro larvae from this eggshell have no apparent belly fins but only a bulge shape. Respiratory and circulatory systems have not been perfect. The mouth and the jaw have not developed and the intestine is still a straight tube. The food comes from the remaining egg yolks that have not been absorbed. The post larvae period is the larval period from the disappearance of the yolk sacs to the formation of new organs or the completion of the extent of the existing organs so that at the end of the post larvae morphologically already have the form almost the same as the parent [6].

Some taxonomic properties that can be used to identify fish are (a) various structures or body parts, such as eyes, head, body shape, stomach and fins; (b) the order of occurrence of its fins and position, photophores and bone elements; (c) larval size; (d) pigmentation and (e) significant signs such as swollen fin folds, elongated and altered fins, choker pricks, thorns on pre-operculum and others [20], [13], [26].

The existence of planktonic larvae is greatly influenced by complex and simultaneous environmental factors, affecting the distribution, live pass rate and fish larvae abundance. Environmental factors affecting the life of fish larvae are numerous and do not work independently, although it is often the case that one factor is more dominant than the other and the factor can be a limiting factor in larval life [20].

The distribution of ichthyoplankton in Segara Anakan Estuary, Cilacap, is strongly influenced by turbidity factor. The abundance of Engraulis larvae (anchovies) in Segara Anakan is significantly associated with salinity and temperature, while the Stolephorus larvae abundance is associated with abundance of zooplankton. The results also show that the ichthyoplankton community in Segara Anakan, Cilacap is more abundant in the interior of estuaries that have smaller environmental variations [17]. The distribution of fish larvae is related to oceanographic conditions of waters and seasons, also strongly influenced by the hydrologic cycle [16]. The peak abundance of fish larvae in Segara Anakan mangrove waters mostly in November and the lowest abundance in January and related to sea level [tide condition] [17]. In St Estuary, South Africa, the distribution and abundance of ichthyoplankton is strongly influenced by the Current Agulhas [10]. The point out the importance of current influences on the distribution of ichthyoplankton in coastal waters of Southeast Australia [10]. Meanwhile, fish distribution in the Gulf of Florida follows salinity gradients from estuaries [15]. The description above showing the distribution of ichthyoplankton somewhere is inseparable from the environmental factors that encompass the environment.

\section{Material and Methods}

Gulf of Teluk Penyu is a coastal ecosystem located in the South of Java Island, precisely in Cilacap district, Central Java. Oceanographic conditions of these ecosystem are strongly influenced by the Indian Ocean such as currents, tides, temperatures and salinity. In addition, Teluk Penyu ecosystem is also influenced by Segara Anakan mangrove ecosystem and several rivers that empties in the vicinity such as the Donan, Kembangkuning, Serayu, Kali Sabuk, Mandiraja and Bodo. These waters is also inseparable from industrial activities such as oil refinery Pertamina UPDN IV, Holcim cement and three electric power plan. Anthropogenic activities of household activities that exist to the waters.

Sampling is done at 3 sites perpendicular to the coastline which distance to coastline 1 mill. Distance between site stations about 2 mills. First Site 1 is located at Teluk Penyu turism beach, $2^{\text {nd }}$ at coastal waters of Cilacap Ocean Fishing Port (PPSC) and $3^{\text {th }}$ site is located in coastal waters of Pertamina Cilacap Hospital (RSPC). Sampling was conducted from April to June 2009.

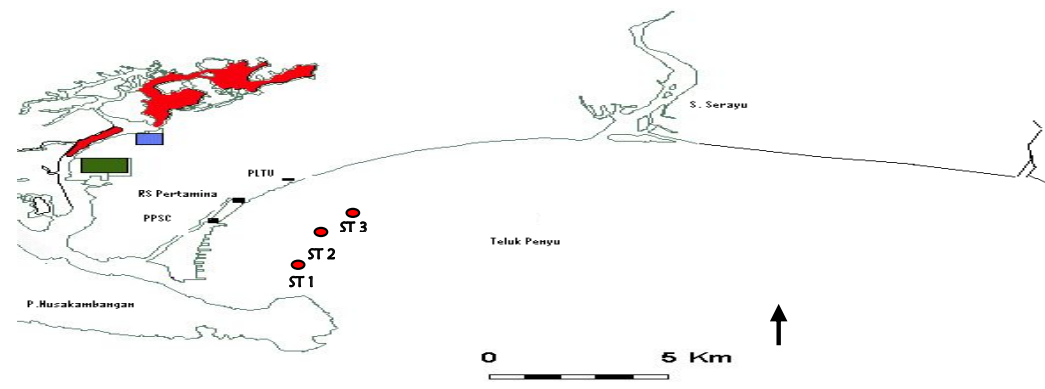

*Author email : marine_2807@yahoo.com 
Fig. 1. Sampling site stations

Sampling was done monthly at each sites. Fish larvae are collected using of meshsize $0,5 \mathrm{~mm}$ and $75 \mathrm{~cm}$ mouth diameter of net larva. The net was towed horizontally 1-2 m under sea surface with boat speed 1 knot for about 30 minutes. Fish larvae were preserved with $4 \%$ of formalin.

The identification of ichthyoplankton is based on [3], [4], [14], [11], [13]. Identification of larvae was done up to the most probable of taxon. The larva was divided by stage larva, post larva or juvenil.

The biological, physical and chemical variables was observed i.e. salinity, temperature, turbidity, brightness, dissolved oxygen, $\mathrm{pH}$, nutrients (nitrate, nitrite, orthophosphate), phytoplankton and zooplankton. Sampling of water for the measurements of variables was performed at each station along sampling of fish larvae.

The composition of the ichthyoplankton species identification unit is describe the richness of ichthyoplankton in Teluk Penyu gulf waters. The composition each site is relatively expressed in percentage (\%) as the ichthyoplankton proportion of species from the total catch $\mathrm{d}$ in each site. The ichthyoplankton abundance is defined as the number of one species per station.

Determination of distribution of water biophysical-chemical variables among observation were analyzed multivariate analysis approach i.e. Principal Components Analysis (PCA) based on [9], [1]. PCA is a descriptive statistical method for presenting in graphical form, the maximum information contained in a data matrix. The data matrix consists of observation stations as individual of larvae (rows) and aquatic biophysical-chemical variables as a quantitative variable (column). Data variables have not same unit of measurement, and before the PCA, data is normalized through centralization and reducing. PCA results are not realized from the initial variable value, but from synthetic indices obtained from linear combinations of initial variable values [12], [1].

Relationship of Ichthyoplankton abundance to aquatic biophysics variables is obtained with multiple regression analysis. The Stepwise method is used to know the relationship between biophysical-chemical variables with ichthyoplankton abundance. Multiple regression analysis was used in accordance with the procedure [9]. The Stepwise method is either a method of multiple regression analysis which begins by the independent variables (in this case environmental parameters) which have the strongest correlation with the dependent variable (larval abundance). Then whenever other free variables are included, testing is carried out by inserting or removing the previous free variable [23]. The PCA and CA calculation process is done by XLSTAT version 5.0 software. Software SPSS version 11.0 is used to calculate multiple regression analysis.

\section{Results and discussion}

\subsection{Ichthyoplankton Abundance}

Distance of observation station in waters was 1 mile from coastal waterline, started from Teluk Penyu tourism beach (TP), Cilacap Ocean Fishing Port (PPSC) and Pertamina Hospital Cilacap (RSPC). The distance between site from Teluk Penyu to PPSC was 1 mile, while the distance between RSPC was 2 miles. Relative Abundance of Inchtyoplankton at each observation site station [see Table 1]

Table 1. Relative abundance of Ichthyoplankton at site stations

\begin{tabular}{|c|c|c|c|c|c|}
\hline No & Spesies & $\begin{array}{l}\text { Scientific } \\
\text { Name }\end{array}$ & T. Penyu & PPSC & RSPC \\
\hline 1 & Sidat & $\begin{array}{l}\text { Anguila } \\
\text { marmorata }\end{array}$ & 0 & 0 & 1.2195 \\
\hline 2 & Gulamah & $\begin{array}{l}\text { Johnius } \\
\text { dussumieri }\end{array}$ & 1.2195 & 0 & 0 \\
\hline 3 & Selar & $\begin{array}{l}\text { Crumrnophthal } \\
\text { mus }\end{array}$ & 41.463 & 31.70 & 0 \\
\hline 4 & Condro & $\begin{array}{l}\text { Tylosurus } \\
\text { crocodilus }\end{array}$ & 0 & 0 & 1.2195 \\
\hline 5 & Belut laut & Anguila $\mathrm{sp}$ & 0 & 1.2195 & 0 \\
\hline 6 & Remang & $\begin{array}{l}\text { Congresox } \\
\text { talabon }\end{array}$ & 0 & 1.2195 & 0 \\
\hline 7 & Pedang & $\begin{array}{l}\text { Chirocentrus } \\
\text { dorab }\end{array}$ & 2.439 & 0 & 0 \\
\hline 8 & Beloso & Saurida tumbil & 1.2195 & 0 & 0 \\
\hline 9 & Ikan Buntal & $\begin{array}{l}\text { Auriglobus } \\
\text { nefastus }\end{array}$ & 8.53667 & 2.439 & 0 \\
\hline 10 & U. Windu & $\begin{array}{l}\text { Penaeus } \\
\text { monodon }\end{array}$ & 0 & 0 & 1.2195 \\
\hline
\end{tabular}




\begin{tabular}{lllrrr}
11 & Lobster & Pannulirus $s p$ & 0 & 3.659 & 3.000 \\
12 & U. Galah & $\begin{array}{l}\text { Macrobranchiu } \\
m \text { sp }\end{array}$ & 0 & 0 & 0 \\
\hline
\end{tabular}

The highest relative abundance was obtained in Teluk Penyu tourism waters $41.463 \%$ of the crawfish [Crumrnophthalmus sp.], followed by pheasant fish (Auriglobus nefastus) 8.53667\%, swordfish [Chirocentrus dorab sp] $2.439 \%$, and beloso [Tumbilic saurida] and gulamah [Johnius dussumieri] which were $1.2195 \%$ [see Fig. 1]

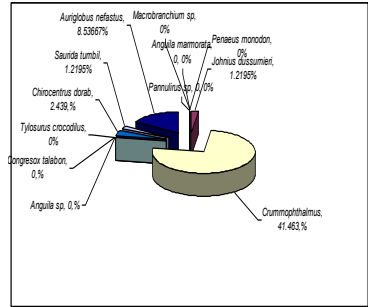

(a)

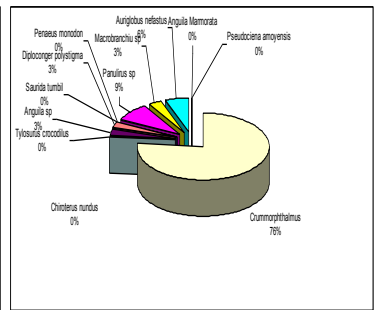

(b)

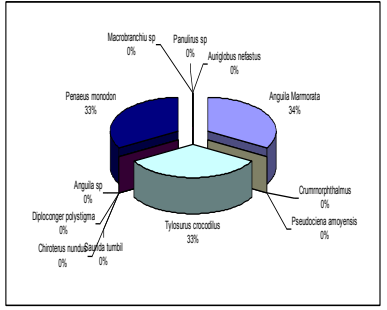

(c)

Fig. 1. Relative Abundance of fish larvae (a) Teluk Penyu tourism of Cilacap waters, (b) PPSC waters and (c) RSPC waters.

The relative abundance of the highest fish larvae species at PPSC station as well as $31,70 \%$ of Crumrnophthalmus sp. Whereas relative abundance in RSPC waters were obtained 3 larvae species. Relative abundance in the waters is obtained sea eel [Anguilla sp], condro fish [Tylosurus crocodilus] which are respectively $1.2195 \%$. Those species above were not found in Teluk Penyu and PPSC stations.

\subsection{Plankton Abundance}

The existence of plankton at sites station in this case includes phytoplankton and zooplankton were obtain difference of abundance [see Table 3]. The highest abundance of phytoplankton in Turism Penyu gulf waters subsequence were obtain Rattulus rattus [35,952,875 ind.100 $\mathrm{l}^{-1}$ ], Astrionella japanica [21,628., 38 ind.100 $\left.\mathrm{l}^{-1}\right]$, and Chaetocheros lorenzianum [18832.664 ind.100 $\mathrm{l}^{-1}$ ]. The abundance of phytoplankton in PPSC waters was dominated by Chaetocheros lorenzianum $\left[177,756,5\right.$ ind.100 $\left.\mathrm{l}^{-1}\right]$. Astrionella japanica $\left[42.774,65\right.$ ind.100 $\left.1^{-1}\right]$ and Nitzschia lorenziana $\left[1,536,096\right.$ ind $\left..100 \mathrm{1}^{-1}\right]$. While the abundance in RS. Pertamina Cilacap waters with the highest order was obtained Astrionella japanica [31,348,2328 ind.100 $1^{-1}$, Chaetocheras lorenzianum $\left[10,068,3795\right.$ ind $\left..100 \mathrm{l}^{-1}\right]$, and Nitzschia lorenziana $\left[8.26,679\right.$ ind.100 $\left.\mathrm{l}^{-1}\right]$.

The highest abundance of zooplankton [see Table 4] in Teluk Penyu tourist site was obtained Chaetoceros sp [9276.1437 ind.100 $\mathrm{l}^{-1}$ ] and subsequent Coelosphaerium dubium [378.594 ind.100 $\mathrm{l}^{-1}$ ] and Platydorina 198.895 ind.100 $\mathrm{l}^{-1}$ ]. Abundance in PPSC with the highest order was Coelosphaerium dubium [407,38 ind.100 $\left.1^{-1}\right]$, Microcystus airruginosa Kutz [93,452 ind.100 1 $\left.{ }^{-1}\right]$, and Bacillaria paradoxa [28.7494 ind.100 $^{-1}$ ]. While the zooplankton zipper in Pertamina waters with the highest order is Chaetoceros sp. [9910.226 ind. $1001^{-1}$ ], Coelosphaerium dubium [558,057 ind.100 ${ }^{-1}$ ], and Rabdonela sp [161.7556 ind.100 $\left.{ }^{-1}\right]$.

Table 3. Phytoplankton abundance

\begin{tabular}{|c|c|c|c|c|}
\hline \multirow{2}{*}{ No. } & \multirow{2}{*}{ Genera [Phytoplankton] } & \multicolumn{3}{|c|}{ bundance (ind. $100 \mathrm{l}^{-1}$ ) } \\
\hline & & $\mathrm{TP}$ & PPSC & RSPC \\
\hline 1 & strionella japanica & 21628.038 & 42774.650 & 31348.232 \\
\hline 2 & iddulphia heteroceros & 256.316 & 98.239 & 165.350 \\
\hline 3 & anthocamptus, sedang kopulatus & 0 & 7.182 & 0 \\
\hline 4 & athypna ungulata & 0 & 7.182 & 0 \\
\hline 5 & haetoceras leave & 93.452 & 187.837 & 50.317 \\
\hline 6 & haetoceras lorenzianum & 18832.664 & 177756.500 & 10068.379 \\
\hline 7 & haetoceras pseudocurvisetum & 237.242 & 424.166 & 100.655 \\
\hline 8 & iatoma & 4.74796 & 0 & 0 \\
\hline 9 & ytilium sol & 83.876 & 59.892 & 57.520 \\
\hline 10 & udorina wallichii & 0 & 50.317 & 0 \\
\hline 11 & emialus indicus & 0 & 7.182 & 0 \\
\hline 12 & emidiscus hardmanianus & 2.394 & 14.364 & 0 \\
\hline 13 & yalotinea disiliensis & 7.182 & 21.567 & 21.567 \\
\hline 14 & emnadia lenticularis & 2.393 & 43.135 & 0 \\
\hline 15 & vngbya spirulinuidae & 0 & 35.953 & 0 \\
\hline 16 & itzschia & 498.445 & 0 & 447.524 \\
\hline 17 & itzschia closterium & 14.385 & 93.452 & 0 \\
\hline 18 & itzschia lorenziana & 1174.129 & 1536.096 & 826.679 \\
\hline 19 & itzschia seratia & 0 & 7.182 & 0 \\
\hline 20 & scillatoria & 14.366 & 79.087 & 14.385 \\
\hline 21 & icillatoria limmosa & 0 & 226.458 & 0 \\
\hline 22 & eridinium & 107.837 & 74.278 & 122.223 \\
\hline
\end{tabular}

Table 4. Zooplankton abundance

\begin{tabular}{|c|c|c|c|}
\hline \multirow{2}{*}{ Genera [Zooplankton] } & \multicolumn{3}{|c|}{ Abundance (ind. $100 \mathrm{l}^{-1}$ ) } \\
\hline & TP & PPSC & RSPC \\
\hline Bacillaria paradoxa & 0 & 28.749 & 28.748 \\
\hline Bacteriastrum varians & 50.316 & 16.757 & 7.182 \\
\hline Brachionus calcyflorus & 7.182 & 14.363 & 0 \\
\hline cepepode & 4.787 & 0 & 0 \\
\hline Ceratium hirudinella & 105.443 & 0 & 0 \\
\hline Ceratium tripos & 105.443 & 0 & 0 \\
\hline Coelosphaerium dubium & 378.594 & 407.38 & 558.057 \\
\hline Cyclops fimbriatus & 26.377 & 21.545 & 43.134 \\
\hline Cyclops fuscus sedang copulatis & 19.173 & 7.182 & 7.182 \\
\hline Cyclops strenuus (cepepoda) & 0 & 7.182 & 0 \\
\hline Dinoflagelata & 0 & 7.182 & 0 \\
\hline \multicolumn{4}{|l|}{ Meta -nauptilus dari cyplops } \\
\hline strenus & 11.9699 & 14.385 & 14.385 \\
\hline Microcystus airruginosa Kutz & 40.740 & 93.452 & 14.385 \\
\hline Nauplius & 98.239 & 26.355 & 157.269 \\
\hline Nauplius cepepode & 21.567 & 0 & 0 \\
\hline \multicolumn{4}{|l|}{ Nauplius cumtocamtus } \\
\hline staphylinus & 0 & 7.182 & 0 \\
\hline Nauplius cyclops srenuus & 2.393 & 14.385 & 0 \\
\hline \multicolumn{4}{|l|}{ Nauplius dari diaptomus } \\
\hline & $n$ & $1100 \%$ & \\
\hline
\end{tabular}




\subsection{Ichthyoplankton abundance and biology, physics and chemistry oceanography}

\section{Ichthyoplankton abundance for each observation station can be known as follows:}
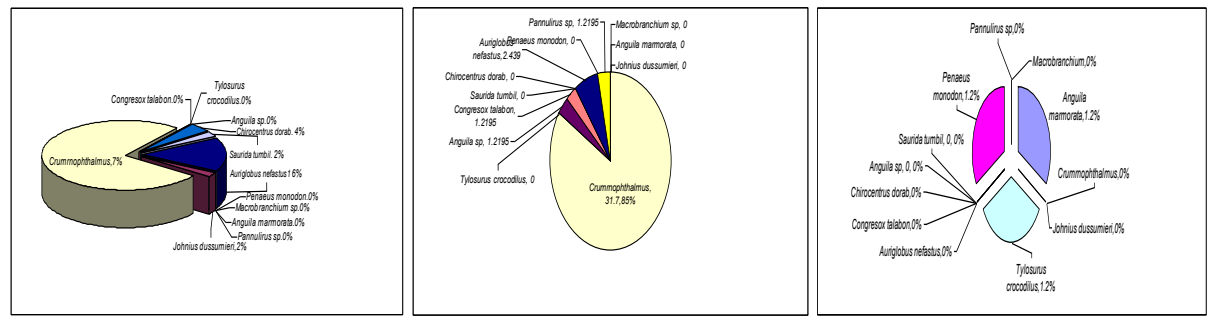

Fig. 2. Ichthyoplankton Relative Abundance (a) Tourism Teluk Penyu (b) PPSC (c) RSPC.

Relative Abundance of individual larvae of ichthyoplankton at each captured site is compared to the total number of larvae. The highest of relative abundance of fish larvae in Teluk Penyu tourism waters was obtained $41.5 \%$ of crawfish larvae [Crumrnophthalmus sp], then puffer fish (Auriglobus nefastus $\mathrm{sp}$ ) 8,5\% and swordfish larvae [Chirocentrus dorab] 2,4\%. Relative abundance of fish larvae in PPSC waters also with the highest number was obtained $31.7 \%$ of Crumrnophthalmus sp, followed by $2.4 \%$ Aurivlobus nefastus sp and sea eel larvae [Anguilla sp], ghost (Congresox talabon) and lobster larvae [Panullirus sp] was $1.22 \%$. While the relative abundance of fish larvae in RSPC was obtained $1.22 \%$ of eel [Anguila marmorata], condro [Tylosurus crocodilus].

4.4 Ichthyoplankton dynamics and biological, physical and chemical parameters

The dynamic of water chemistry-biophysical parameters at each observation station can be seen as follow :

Table 2. Dynamic of biophysic-chemis and phyto-zooplankton abundance.

\begin{tabular}{lccccccccccc}
\hline & \multicolumn{1}{c}{ Oceanographic Parameters } \\
\cline { 2 - 11 } \multicolumn{1}{c}{ Stasion } & A & B & C & D & E & F & G & H & I & J & K \\
\hline T.Penyu & 30.7 & 0.34 & 30.3 & 38.3 & 3.97 & 7.8 & 3.05 & 0.05 & 0.64 & 21628.04 & 9276.1 \\
PPSC & 31.7 & 0.57 & 30.3 & 30.3 & 5.23 & 8 & 1.61 & 0.11 & 0.07 & 177756.5 & 407.38 \\
Pertamina & 31 & 0.77 & 31 & 31 & 5.67 & 8 & 1.9 & 0.09 & 0.08 & 31348.23 & 9910.2 \\
\hline
\end{tabular}

A [Temperature $\left.{ }^{\circ} \mathrm{C}\right], \mathrm{B}$ [current velocity $\mathrm{ms}^{-1}$ ], C [Salinity ppt], D [Clerarity], E [DO], F [pH], G [Nitrat], $\mathrm{H}$ [nitrit], I [Posphat]. J [Phytoplankton abundance (ind. $100 \mathrm{1}^{-1}$ )], K [Zooplankton abundance (Ind.100 1 $\left.\left.1^{-1}\right)\right]$

Teluk Penyu gulf waters are generally semi-closed areas. Biological and oceanographic conditions are influenced by fluctuations pattern of tidal currents of the Indonesian ocean and geographical of coastal conditions. Tidal current type of Cilacap waters is semi diurnal which two springs and neaps daily. The coastline stretching from the boundary of Cilacap at Eastern border curving to form a circular arc towards the Western boundary and leading to South, thus the pattern of tidal currents along the coast from the East to the West and South along the Southern boundary. Such conditions result in pairs of organic materials accumulate in the Southern boundary. These indication are known the dissolves of organic material in the waters on sampling time, with organic soluble material more in the direction of in the South of the curved boundary, namely the mouth Tanjung Intan ships cannel or East Plawangan. Those conditions cause the waters of South part Teluk Penyu waters relatively more fertile than the waters in the Eastern. Indicator of the condition is known by the abundance of phytoplankton and zooplankton higher than the abundance PPSC and RS.PC site stations at Eastern [Table 2]. Association of the abundance of ichthyoplankton at each observation decrease in the Eastward direction, and the high abundance is obtained in the Teluk Penyu tourism waters. 


\section{Conclusion}

The fertility of coastal waters is influenced by the hydrologic cycle and geographical conditions, furthermore influence the abundance of phytoplankton and zooplankton. Those abundance associated the ichthyoplankton abundance. Southern of Teluk Penyu gulf waters was highest abundance area of ichthyoplankton.

\section{References}

1. Bengen, D. G. Fakultas Perikanan dan Ilmu Kelautan IPB. 88 pp (2000)

2. Blaber, S.J.M., D.P. Cyrus, J.J. Albaret, C.V. Ching, J.W.Day, M. Elliot, M.S. Fonseca, D.E. Hoss, J. Orensanz, I.C. Potter, and W. Silvert. Journal of Marine Science. 57 : 590-602 (2000)

3. Delsman, H. C. Treubia. VIII : 109-254 (1926)

4. Delsman, H. C. Treubia. XIV : 109-254 (1932)

5. Dinas Kelautan dan Perikanan Kabupaten Cilacap. Data Produksi Perikanan Kabupaten Cilacap. 234 pp (2002)

6. Effendie, M.I. Yayasan Pustaka Nusatama, Yogyakarta (1997)

7. Ekau, W, P. Westhaus-Ekau and C. Medeiros. Archive of Fishery Marine Research. 47(2/3) : 183-200 (1999)

8. Gray, C.A and A.G. Miskiewicz. Coastal and Shelf Science. 50 : 549-570 (2000)

9. Hair, J.F., R.E. Anderson, R.L. Tatham and W.C. Fifth Edition. Prentice-Hall International, Inc, London. 432 pp (1998)

10. Harris, S.A., D.P. Cyrus, and L.E. Beckley. Estuarine, Coastal and Shelf Science. 49 : $789-811$ (1999)

11. Jayaseelan, M.J.P. UNESCO Publishing. 193 pp (1998)

12. Legendre, P. and L. Legendre. Elsevier Science, Amsterdam (1998)

13. Leis, J. M and B.M. Carson-Ewart (eds). Brill, Leiden. 850 pp (2000)

14. Leis, J.M and Rennis, D.S. New South Wales University Press, Sydney. 269 pp (1983)

15. Ley, J.A., C.C. McIvor and C.L. Estuariane, Coastal and Shelf Science. 48 : 701-823. 1999.

16. Nurdawati, Syarifah. Jurnal Penelitian Perikanan Indonesia. 13 (2) (2007)

17. Nursid, M. Jurnal Ilmu-Ilmu Perairan dan Perikanan Indonesia. 14 (1), 45 - 51 (2007)

18. Nursid, M. Tesis. Program Pascasarjana Institut Pertanian Bogor, Bogor. (tidak dipublikasikan). 63 pp (2002)

19. Okiyama, M. (ed). Tokay University Press, Tokyo. 1154 pp (1989)

20. Romomihtarto, K dan S. Juwana. Plankton Pusat Penelitian dan Pengembangan Oseanologi Lembaga Ilmu Pengetahuan Indonesia. Jakarta (1998)

21. Russel, F.S. The 456 pp (1976)

22. Sanchez-Velasco, L., C. Flores-Coto and B. Shirasago. Estuariane, Coastal and Shelf Science. 43 : 707-721 (1996)

23. Santoso, S. PT. Elex Media Komputindo, Jakarta. 432 pp (2000)

24. Tomigama, O. Fisheries Science. 66 (3) : $442-451$ (2000)

25. Unesco Technical Papers in Marine Science. Report of the CICAR Ichthyoplankton Warkshop. Mexico City. 42 pp (1975)

26. Westhaus-Ekau, P. Series Course on The Sea and Its Resources. Jenderal Soedirman University, Faculty of Biology, Purwokerto. 54 pp (2002) 